\title{
Premarital Cohabitation of Young People. Features of Interpersonal Relations in Trial Common-Law Marriage
}

\author{
Larisa Argentova \\ Department of Psychological Sciences of Socio-Psychological \\ Institute of \\ Kemerovo State University \\ Kemerovo, Russia \\ argentovalora@gmail.com
}

\author{
Tatiana Argentova \\ Department of Psychological Sciences of Socio-Psychological \\ Institute of \\ Kemerovo State University \\ Kemerovo, Russia \\ argentovat@gmail.com
}

\begin{abstract}
The number of the so-called "cohabitation marriages" has recently been increasing in Russia. The article features civil marriages typology: it gives a detailed classification of the so-called "trial" marriages and lists the factors contributing to the growth of cohabitation among youth. The research included a comparative study of the relationships between partners in cohabitation and registered marriages. The results obtained have demonstrated significant differences in inter-marital relations between representatives of both types of marriages. The authors considered the pros and cons of the relationships between partners in trial marriages; they emphasize the ambiguity of attitudes to the interpersonal relations phenomenon.
\end{abstract}

Keywords - common law marriage, "trial" marriage, marital relations, family values, role expectations of partners

\section{INTRODUCTION}

Male - female relations create the basis of life. Any successfully functioning society depends on social institutions of marriage, family, and intergenerational continuity.

It is the family environment that establishes foundations for one's personality. Family is the pillar of any state and its future. At the same time, family is not a static institution: it is currently undergoing some major changes, one of them being the so-called trial marriage: more and more young couples prefer cohabiting to traditional official marriage [6].

Some Russian researchers believe unregistered marriage to be an alternative form of marriage and family relations, which they see as new relation forms that sprung from the ruins of the old traditional patriarchal family (I.V. Bestuzhev-Lada, A.K. Vishnevsky, S.I. Golod, L.V. Kartseva, I.S. Kon, A.B. Orlov, V. Stankunene, L.B. Schneider, et al.) $[1 ; 2 ; 7 ; 11]$. Others claim that civil marriage results from the crisis of the institution of marriage and manifests its dysfunction (E.G. Eidemiller, V.V. Yustitsky) $[1 ; 2 ; 11]$, its fragmentary (A.I. Antonov, V.M. Medkov) [7] and abnormal nature (V.N. Druzhinin) [1]; moreover, the sheer existence of civil marriage augers a possible collapse of the family way of life, being a sign that family pillars are getting unstable and require additional support.

In this sense, the current state of the family can be defined as a state of transition, a marginal one. This state is characterized, on the one hand, by a weakening of the traditional, well-recognized social orientation of the family, and, on the other hand, by a complex of poorly comprehended family life determinations.

On the surface, these processes of reorientation of the traditional family are manifested in the form of its permanent crisis, destabilization, disharmonization, and disintegration, which results in the ever growing number of divorces. However, behind these external negative symptoms there are much more positive processes of human liberation, one's search for authentic personality and true self.

The representatives of the humanistic approach believe that the crisis of the family is a manifestation of the current crisis of human identity, which is inextricably linked with the processes of one's individuation and authentication. To overcome the crisis of the family, it might require annihilation of its most institutionalized form, i.e. socially sanctioned marriage.

Individuals involved in a civil marriage demonstrate different motivations; therefore, this form of cohabitation has a lot of supporters who believe that the uncertainty of marital relations stimulates mutual respect, encourages personal growth and responsibility, and ensures economic independence.

On the other hand, the absence of official registration of marital relations can result in opposite marital and family expectations: in such an alliance, women may consider themselves married, whereas men truly believe that they are single. In a situation of an intractable disagreement, it facilitates the separation of partners, making unregistered marriage less stable. 
According to various sources, about $10 \%$ of Russians currently live in civil, or common-law marriage. In 2016, about $14 \%$ of Kemerovo region citizens practiced such kind of cohabitation. In 2016, $27 \%$ of local children were born "out of wedlock" [7].

The so-called "civil" marriage is not uniform. In 2010, the authors proposed a marital typology based on the age of partners and the presence of registered marital relations and children in their past [1]:

1. Trial marriage between young people (hereinafter, $\mathbf{T M}$ );

2. Common law, or civil marriage as an alternative family relations, when partners consciously detain from registering their relationships for various reasons, even after the birth of children (often after disappointments in previous marriage);

3. Friendly union of people of mature age, widowed or longdivorced. Often this kind of cohabitation occurs for economic reasons or out of loneliness $[1 ; 3]$.

The authors have focused their attention on a detailed study of interpersonal relations in unregistered marriages. Most often, such relationships have been initiated by divorced men in their $30-40$, with negative family life experience and children from previous marriages. They deliberately avoid official registration of their new relations, even after these relations result in the birth of a child (children).

Such relations tend to be short-lived, and there is always a danger that a civil marriage will leave the woman a single mother. If an unregistered marriage does get legalized, its legitimation is preceded, as a rule, by some very significant events.

According to the research conducted by T.E. Argentova and N.N. Lidovskaya, the relationships of unregistered spouses are different from those in official marriage, e.g. they are characterized by autonomy, independence orientation, or, on the contrary, distrust and dependence, as well as by emotional instability, male domination and female subordination; the spouses demonstrate a much lower degree of marriage satisfaction [2].

The woman finds herself in a less favorable position, because her marriage choice is secondary and depends on the marriage choice of the man; she has to agree to cohabitation, while experiencing cognitive dissonance (according to L.Festinger), caused by a role conflict [2].

While the fact that unregistered marriage is extremely wide-spread mitigates the dissonance, it does not eliminate differences in the relationship of spouses compared with those in officially registered marriages.

But as far as TM is concerned, it has remained outside the scope of research so far.

The TM type stands apart in the classification mentioned ablove. Quite often the young partners involved are not ardent opponents of official marriage. In most cases, this type eventually results in an official registration of relations.

TM usually involves young people under 30 without previous martial experience or children. The experience and results of TM shape the concept of real marriage and attitude towards it, thus defining private and family life and the demographic situation in the country as such.

Several factors contribute to the increase in cohabitation type of marriage among the youth:

- development of effective contraception methods, which leads to an expansion of the boundaries of sexual loyalty;

- $\quad$ pre-marital cohabitation is accepted by the society not as a norm, but as a "minor sin";

- $\quad$ improvement of the material well-being of young people and, as a consequence, a decrease in their dependence on parents, which gives them an opportunity to move out and live according to their own rules;

- $\quad$ long period of education and career development, which postpones the age of marriage and childbirth;

- $\quad$ infantilism of the modern youth, who do not want to take responsibility for the spouse and children, quite often as a result of the fact that they come from a singlemother kind of family;

- career-oriented upbringing of girls, when higher education and career are given topmost priority, while leaving behind such stereotypical female skills as the ability to care after others, to resolve conflicts, to look after the house, etc. It also involves the unrealistic demands that girls have to "have it all".

Consequently, cohabitation among the young citizens has become a wide-spread practice but remains insufficiently studied. Besides, the relevance of the subject is underlined by the fact that experience which spouses gain in TM affects their decision whether to enter official marriage or not.

The subject of the current study is the relationship between young partners in TM in comparison with their officially married peers.

The methodological basis has been shaped by the following approaches:

- a humanistic approach to the examination of the personality in the system of interpersonal relations (A. Maslow, K. Rogers, E. Fromm, K. Horney, V. Frankl, G. Allport, R. Mei, L.Ya. Gozman, V.I. Kabrin, A.A. Kronik, E.A. Kronik, A.B. Orlov, et al). According to the view, any individual naturally aspires to freedom and self-actualization in the direction of personal growth, creativity and selfsufficiency, which is realized in close intimate relations as mature experience of productive love based on the manifestation of care, responsibility, respect, and knowledge, through the experience of unity with the other while maintaining one's own sense of wholesomeness and independence $[2 ; 7 ; 11 ; 13 ; 14 ; 15]$;

- a systematic approach to the family (as a subsystem of marital relations) (M. Bowen, V. Satir, S. Minukhin, A.Ya. Varga, A.G. Liders, O.A. Karabanova, et al.). This approach considers marital relations as a random choice of a spouse $(R$. 
Winch, A. Kergoff, K. Davis, B. Murstein, R. Centers, R. Mei, K. Rogers, E. Fromm, K. Horney, Yu.E. Aleshina, L.Ya. Gozman, I.S. Kon, V.N. Druzhinin, N.N. Obozov, A.N. Obozova, S.V. Kovalev, L.N. Sobchik, A.N. Volkova, T.M. Trapeznikova, et al.). The relationship is built on the basis of the partners' ideas about the family and marriage, the norms in marital relations, which are organized into expectations, attitudes, and needs $[2 ; 7 ; 9 ; 10]$. Spouses either adapt and achieve compatibility or fail to do it because they misinterpret each other's behavior, while having different values, goals, needs, life experiences, and attitudes.

\section{Research hypothesis:}

1. Relations in an unregistered TM are different from those between officially married young spouses.

2. Distinguishing features involve: attitude towards the partner; family values; causes and types of intra-familial conflicts; marriage satisfaction.

Theoretical and methodological core of the research has been shaped by the works of foreign and Russian psychologists, specializing in the issues of matrimonial relations (T. V. Andreeva, L. L. Bumpass, B. Whitehid, A. Y. Varga, R. Winch, K. Vitek, V. N. Druzhinin, A. Kerkoff, A. G. Liders, O. A Karabanova, S. Cartwright, S. Kratochvil, N. N. Lidovskaya, G. A. Nawaitis, D. Popenoe, A. S. Spivakovskaya, V. A. Sysenko, V. Satir, L. B. Schneider, E. G. Eidemiler, et al) $[1 ; 10 ; 12 ; 14]$.

For mathematical processing of data, Statistica software package was used.

Description of selection: The experimental group (EG) consisted of 60 unregistered couples aged 19-30; the control group (CG) included 60 registered couples of the same age. The survey involved university students, as well as young people engaged in various social spheres, mainly with higher or secondary special education. All the respondents live in Kemerovo and Kemerovo region. The study was conducted between January and September 2017.

In EG, the average period of cohabiting was 2.3 years, in $\mathrm{CG}-2.1$ years. None of the subjects had previous marriages or children. Most of the couples surveyed dwelled in rented apartments or in a dormitory, and, in an insignificant number of cases, in property belonging to one of the partners.

\section{RESUlts AND DiscUSSION}

\section{Exposition and analysis of research results}

Research of styles of spouses' relations in official and unregistered marriages was conducted by using the technique of "Styles of interpersonal relations" by T. Leary in L. N. Sobchik's adaptation [3]. The study results are presented in Table 1.

The research has revealed statistically significant differences in the relationship of men to women and women to men in TM, and contrast in what they want from each other. The CG couples have not displayed such differences, i.e. in their opinion, the behaviour of their spouses is close to ideal. We can assume that the results can be explained by the fact that the spouses are still at the initial stage of matrimonial relations and have no children so far.

In general, EG men have fewer significant differences in the estimates of real and ideal partners: they live with the partners they would like to be with. However, they would like to see their partners more obedient and dependent than CG men. The situation is different for TM female partners, who want their men to be less authoritarian and less selfish.

EG women, if compared to $\mathrm{CG}$ women, showed a more distinct style of attitude towards the partner: they want to get married officially. Therefore, despite the current level of female emancipation, modern women still value marriage, and family remains their top priority.

The study of consistence of family values in partners from both groups, as well as between men and women within groups, was carried out with the help of "Role expectations of partners" methodology by A. N. Volkova [5]. The study results are presented in Table 2.

The research has shown that TM partners have significantly higher indicators of consistency of family values, such as sexual and social activity, and significantly lower indicators of consistency in personal identification compared with CG spouses. At the same time, both sexual and social activity is more important for men; for TM men, the external attractiveness of the partner is significantly more important. It should be added that such spheres as intimate-sexual, social activity and visual appeal have a higher significance for men.

TM women focus on active participation in domestic issues, thus attempting to implement their image of "real", officially registered marriage. Men, however, display a less pronounced attitude to participation in household management.

The survey conducted in $\mathrm{CG}$ has not revealed any statistically significant differences in common values of spouses. Men give yet a little more importance to the values of personal identification, and women overestimate their own visual appeal. As for household management, this sphere also remains priority value for wives.

The study of causes for conflicts between spouses in both groups was carried out according to the method "The nature of the interaction of spouses in conflict situations" by $\mathrm{Y}$. E. Aleshina, L. Y. Gozman $[1 ; 3 ; 5]$. The study results are presented in Table 3.

According to the results, more frequent causes for conflicts in the relationships of spouses in TM, compared with their registered peers, involve:

- desire of both partners for autonomy, independence, freedom (men need it slightly more);

- breaching of role expectations (women claim that men do it more often);

- manifestations of jealousy towards each other, though men display jealousy more often; 
In addition, women in TM significantly more often named authoritativeness of men as the cause for conflicts, while men from registered marriages blamed the same on their wives. It can be assumed that women begin to feel more confident after their marriage. Spouses in registered families significantly more often indicate that the cause for conflicts lies in money issues and ways of earning and spending it.

The study of marriage satisfaction of men and women from EG and CG was conducted according to the "Questionnaire of marriage satisfaction" methodology by V. V. Stolin, T. L. Romanova, and G. P. Butenko [1;3; 8]. The study results are presented in Table 4 . They have revealed a significantly lower satisfaction level among TM partners, compared with spouses in an official marriage. Men are generally more satisfied with relationships than women. It can be explained by the theory of secondary choice, according to which women choose only from those men who have chosen them. As a rule, it's a great joy for partners when their choices coincide.

Plans for shifting from cohabitation marriage to officially registered marriage. The survey is presented in Table 5. Only $20 \%$ of men and $26,7 \%$ of women plan to enter official marriage. The rest are satisfied by the current situation.

\section{CONCLUSION}

The research results suggest that some aspects of TM type of common-law marriage are controversial.

In the beginning of any relationships, partners' interests, especially those of men as the leading partners, focus on sexual attraction and joint leisure time. These keep partners together during this period of their relationships, which is quite natural for the young. Men place great importance on their women's visual attractiveness, displaying my-woman-is-my-trademark kind of attitude: he wants to be proud of her and sees her as an extension of his social self.

Thus, men pay a lot of attention to the consistency of such family values as intimacy, sex, visual attractiveness, and social activeness while giving a lower priority to the personal identification with the partner (they are not mature enough for such intimacy). As for the emotional and psychotherapeutic values, together with the value of the joint household, they are priorities of officially married men. They demonstrate a different attitude towards marriage and their spouses: they look not only for sex and visual attractiveness, but also for the spiritual intimacy.

However, the undeniable advantage of TM is that the partners have an opportunity to know each other directly in the real everyday life, thus learning how to build marital relationships. A lot of young people's illusions about each other get dispelled, their claims become more realistic. The partners adjust to each other, set up their boundaries, deal with the question of power, quarrel, demonstrate domination, aggression, suspicion, selfishness towards each other, until they create desired relationships or break up and start searching for new partners.

The main conflicts in TM are connected with 1) the desire for independency and freedom, both in men and in women (they act as if they were single, unmarried people who do not have to inform anyone about their actions or intentions), 2) the disorder of the role expectations (men's behavior does not correspond to women's concept of masculine behavior and vice versa), 3) the display of jealousy towards each other. Apart from that, women in TM significantly more often name men's tendency to demonstrate domination as the cause of conflicts.

TM partners are less satisfied with their relationships than officially married ones. It seems that despite the alleged liberty in the relationships, most women share traditional view on the family, which makes them more dissatisfied with the civil marriage relationships: they seek more stability for themselves and their future children. They would like their partners to act in a more responsible and serious manner.

According to the research results, marriage registration has a positive influence on the marital relationships: everyone settles down, women feel more confident, they become more satisfied with themselves and start sharing their wants and needs with their husbands, who, in their turn, start trusting their wives and listening to their opinion. The main reasons of conflicts between married spouses are related to money, which does not happen in TM, where partners do not have common budget in its full sense.

It is important that cohabitation of young people should not result in their disappointment in marriage as a social institution. Unfortunately, up to two-thirds of men and women find cohabitation satisfactory, which is a lot, considering the fact that average relations last two years, and childbirth is delayed. Whether TM eventually couples get married or not, depends on the couple's (or one from the partners) view on benefits of unregistered relations, whose biggest advantage is a troublefree break-up and absence of responsibility.

It seems that young people need a more vigorous promotion of family values from the state (media, religious and social organizations, educational institutions) and their own parents. Whereas the publicity for contraceptives and safe sex is quite high, movies and television continue broadcasting an image of exhausted, homely looking mothers, not knowing what to do with their constantly crying babies. The charm and beauty of mothers and children, together with various advantages of the family way of life remain behind the scenes. At the same time, mass media popularize the advantages of bachelor life, when 40-50-year-old men still remain machos and become fathers in their 60s. In the situation when sexual pleasures are easy to get and social control is practically absent, young people see no need to hurry.

As a result, psychologists encounter terrific numbers of women in their 30s-40s who affected by loneliness. At the same time, men of modest means have nothing to offer a young girl who "wants it all". After a while such a girl realizes the difference between her high aspirations and the harsh reality, especially if she herself has not much to offer in terms of appearance and intelligence. The current Russian reality is that she can rely on herself and herself only, relations with no strings attached being the only remaining option. 


\section{REFERENCES}

[1] L. V. Argentova, T. E. Argentova, "Common-law marriage as the main alternative form of traditional marriage," in "Personality in the postcrisis socio-cultural environment: risks, potentials of development: collected articles of II International scientific-practical conference on November 11-12, 2010" / Kemerovo State University. - Kemerovo, pp. 66-71, November 2010.

[2] T.E. Argentova, N.N. Lidovskaya, "Comparative study of problems in the relationship of spouses with registered and unregistered marital relations", in "Siberian Psychological Journal", vol. 25, 2007, pp. 132 136.

[3] L. P. Bogdanova, A. C. Shchukina, "Common-law marriage in the modern demographic situation", retrieved March 15, 2018, from: demoscope.ru/weekly/2005/0191/analit04.php

[4] L. F. Burlachuk, "Psychodiagnostic: Textbook for universities (Series "Textbook of the new century")", St. Petersburg: Piter, 2006.

[5] E. Vovk, "Unregistered intimate unions: varieties of marriage or alternatives to it?", retrieved March 15, 2018, from: www.demoscope.ru/weekly/2006/0237/tema01.php

[6] A. N. Volkova, "Methodical technique of diagnosis of marital relations", in "Questions of psychology", vol. 5, 1985, pp. 68-73.

[7] S. I. Golod "Socio-demographic analysis of the status and evolution of the family", Sotsis, vol. 1, pp. 42-45, 2008.
[8] Internet portal of Russian Federal State Statistics Service of Kemerovo region, retrieved March 15, 2018, from: www.kemerovostat/ru/statistics/population

[9] A. G. Liders, "Psychological examination of the family: study manual - workshop for students of psychological faculty," in "Psychologists of the universities", Moscow: Academy, 2007.

[10] L. N. Petrova, "Unregistered marriages and social consequences", Scientific notes of RSSU, vol. 10, 2009, pp. 202-207.

[11] A. A. Rean, T. V. Andreeva, "Psychological problems of common-law marriage", retrieved March 15, 2018, from: www.psibook.com/articles/psihologicheskie-problemy-grazhdanskogobraka.html

[12] L. L. Shpakovskaya, "Unregistered unions: marriage strategies of young representatives of the urban middle class", in "Woman in Russian society", vol. 1, 2012, pp. 3-16.

[13] L. L. Bumpass, "Cohabitation, Marriage and Union Stability: Preliminary Findings from NSFH2", University of Wisconsin, 1995.

[14] "Is cohabitation a good choice? Living together", retrieved March 10, 2003, from: marriage.about.com/cs/cohabit/

[15] D. Popenoe, B. D. Whitehead, "What Young Adults Need to know about Cohabitation before Marriage. A Comprehensive Review of Recent Research", retrieved March 9, 2003, from: marriage.about.com/cs/cohabit/

\section{APPENDIX}

Styles of spouses' relations from experimental group (EG) and control group (CG).

\begin{tabular}{|c|c|c|c|c|c|c|}
\hline Relationship styles & \multicolumn{3}{|c|}{ Experimental group } & \multicolumn{3}{c|}{ Control group } \\
\hline $\begin{array}{c}\text { Comparison of real and ideal } \\
\text { behaviour by style criteria }\end{array}$ & $\begin{array}{c}\text { Median } \\
\text { (women } \\
\text { evaluate } \\
\text { men) }\end{array}$ & $\begin{array}{c}\text { Median } \\
\text { (men } \\
\text { evaluate } \\
\text { women) }\end{array}$ & $p$ & $\begin{array}{c}\text { Median } \\
\text { (women } \\
\text { evaluate } \\
\text { men) }\end{array}$ & $\begin{array}{c}\text { Median } \\
\text { (men } \\
\text { evaluate } \\
\text { women) }\end{array}$ & $p$ \\
\hline Authoritativeness & 4.13 & 2.47 & 0.003 & 1.67 & 1.60 & 0.85 \\
\hline Selfishness & 2.13 & 1.47 & 0.04 & 1.5 & 1.9 & 0.27 \\
\hline Distrustfulness & 2.7 & 1.93 & 0.07 & 1.4 & 1.97 & 0.09 \\
\hline
\end{tabular}

Results of study of consistence of family values among men and women from EG and CG.

\begin{tabular}{|l|c|c|c|c|c|c|}
\hline \multirow{2}{*}{\multicolumn{1}{|c|}{ Family values }} & \multicolumn{3}{|c|}{ Men } & \multicolumn{3}{c|}{ Women } \\
\cline { 2 - 7 } & $\begin{array}{c}\text { Median } \\
(E G)\end{array}$ & $\begin{array}{c}\text { Median } \\
(\boldsymbol{C G})\end{array}$ & $\boldsymbol{p}$ & $\begin{array}{c}\text { Median } \\
(\text { EG })\end{array}$ & Median (CG) & $p$ \\
\hline Intimate-sexual & 6.4 & 4.47 & 0.00007 & 5.9 & 4.3 & 0.0003 \\
\hline $\begin{array}{l}\text { Personal identification with } \\
\text { spouse }\end{array}$ & 2.9 & 6.17 & 0.000001 & 4.5 & 5.83 & 0.009 \\
\hline Household management & 4.77 & 5.5 & 0.04 & 5.8 & 6.15 & 0.4 \\
\hline Social activity & 7.27 & 6.3 & 0.001 & 6.55 & 5.65 & 0.0006 \\
\hline Emotional-psychotherapeutic & 5.53 & 6.58 & 0.0004 & 5.63 & 6.65 & 0.002 \\
\hline
\end{tabular}




\begin{tabular}{|l|l|l|l|l|l|l|}
\hline Visial appeal & 6.57 & 5.1 & 0.0004 & 6.82 & 6.7 & 0.79 \\
\hline
\end{tabular}

Causes for conflicts in the opinion of men and women from EG and CG

\begin{tabular}{|c|c|c|c|c|c|c|}
\hline \multirow{2}{*}{ Types of conflict situations } & \multicolumn{3}{|c|}{ Men } & \multicolumn{3}{c|}{ Women } \\
\cline { 2 - 7 } & Median $($ EG $)$ & $\begin{array}{c}\text { Median } \\
(\boldsymbol{C G})\end{array}$ & $\boldsymbol{p}$ & Median (EG) & Median $(\boldsymbol{C G})$ & $p$ \\
\hline The desire for autonomy & -0.77 & 1.4 & 0.003 & -0.4 & 1.03 & 0.03 \\
\hline Difficulties in role expectations & 0.13 & 2.17 & 0.009 & 0.03 & 2.27 & 0.005 \\
\hline Manifestation of dominance & 0.7 & 0.83 & 0.82 & -0.77 & 0.97 & 0.004 \\
\hline Manifestations of jealousy & -0.9 & 1.27 & 0.007 & -0.37 & 1.47 & 0.02 \\
\hline Disagreements about money & 0.83 & -1.27 & 0.02 & 1 & -1.53 & 0.0007 \\
\hline
\end{tabular}

Marriage satisfaction of men and women from EG and CG

\begin{tabular}{|l|c|c|c|c|c|c|}
\hline \multirow{2}{*}{ Marriage satisfaction level } & \multicolumn{3}{|c|}{ Men } & \multicolumn{3}{c|}{ Women } \\
\cline { 2 - 7 } & Median (EG) & Median (CG) & $\boldsymbol{p}$ & Median (EG) & Median (CG) & $\boldsymbol{p}$ \\
\hline Marriage satisfaction & 32.87 & 36.90 & 0.001 & 32.47 & 36.27 & 0.003 \\
\hline
\end{tabular}

Plans for shifting from cohabitation to officially registered marriage

\begin{tabular}{|c|l|l|}
\hline $\begin{array}{c}\text { Plans for shifting from cohabitation marriage to officially } \\
\text { registered marriage }\end{array}$ & Men & Women \\
\hline Planning to do so within a year & 20 & 26.7 \\
\hline Current situation is satisfactory & 80 & 73.3 \\
\hline
\end{tabular}


